\title{
Drop-in Performance Analysis and Effect of IHX for an Automotive Air Conditioning System with R1234yf as a Replacement of R134a
}

\author{
Mehmet Direk ${ }^{1, *}$ - Alper Kelesoglu ${ }^{2}$ - Ahmet Akin ${ }^{2}$ \\ 1 University of Yalova, Faculty of Engineering, Turkey \\ 2 University of Yalova, Institute of Science and Engineering, Turkey
}

This paper presents the experimental comparative performance analysis of an automotive air conditioning (AAC) system using R1234yf and R134a. For this purpose, an AAC experiment setup used for R134a was built to obtain the drop-in performance of a new refrigerant R1234yf. Among the low global warming potential (GWP) refrigerants, R1234yf was particularly chosen due to its similar thermo-physical properties with R134a. However, the system with R1234yf could not perform as efficiently as R134a can. Therefore, an internal heat exchanger (IHX) was employed to enhance the performance of the R1234yf system. After that, the performances of R1234yf and R134a were compared under various compressor speeds and air stream temperatures. The results showed that the cooling capacity and COP of the system with R1234yf were $17.1 \%$ and $12.4 \%$, respectively, lower compared to the one with R134a. However, when the IHX was introduced into the system with R1234yf, the cooling capacity and COP values were significantly enhanced by $7.9 \%$ and $4.1 \%$, respectively.

Keywords: R134a, R1234yf, automotive air conditioning, internal heat exchanger

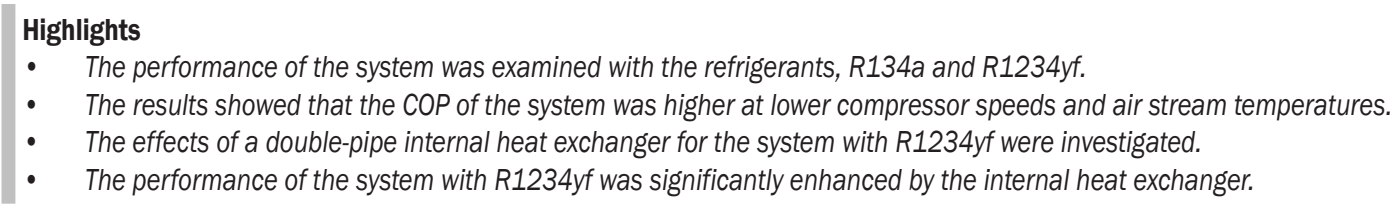

\section{INTRODUCTION}

Nowadays, one of the biggest problems for humankind is global warming caused by increased greenhouse gas emissions. Regarding to the global warming, the limitation studies for the usage of chlorofluorocarbon (CFC), hydrochlorofluorocarbon (HCF), and hydrofluorocarbon (HFC) continues. The usage of refrigerants that have GWP values higher than 150 in new AAC systems was restricted in 2006 by the European Parliament MAC Directive [1]. With the European Parliament Regulation No 517/2014, the MAC Directive is reconsidered and the usage of higher GWP refrigerants such as R134a (GWP value 1430 ) in AAC systems was planned to be prohibited starting from the year 2022 [2]. In contrast, European Parliament Regulation No 206/2012 stated that from 2014, small air conditioning systems up to $12 \mathrm{~kW}$ must supply coefficient of performance (COP) values at least 1.62 and 1.80 for the refrigerants that have GWP values higher and lower than 150, respectively [3]. Even though R134a can achieve the represented COP value in small air conditioning systems, its usage was prohibited by European Parliament Regulation No $517 / 2014$. Therefore, finding an alternative refrigerant to R134a became an important task. Recent studies showed that R1234yf had significant potential as an alternative and possible replacement for R134a in AAC systems. Furthermore, cooling capacity and COP values of R1234yf could be quite similar to R134a by only applying a few simple system modifications [4]. R1234yf has similar thermo-physical properties with R134a and therefore there is no necessity for a significant change to the system. Additionally, R1234yf can be charged to the system $10 \%$ lower than R134a because of lower vapour density at higher refrigerant vapour temperature [5]. Zilio et al. [6] used R1234yf in conventional R134a AAC system which has a nominal cooling capacity of $5.8 \mathrm{~kW}$. They found that R1234yf can be used in direct expansion applications because of the mild flammability properties. Qi [7] discussed the improvement potentials of R1234yf based on the simplified thermodynamic cycle analysis. He found that the system with R1234yf has $4.8 \%$ to $7 \%$ and $7.7 \%$ to $10.6 \%$ lower COP and cooling capacity values than R134a did. Abdelaziz et al. [8] made an experimental analysis to compare the performance of R134a and R1234ze. The results indicate that R1234ze has $16 \%$ lower energy consumption than R134a did. Cho and Park [9] investigated the performance of AAC system with R1234yf. The results showed that the system with R1234yf has $3.4 \%$ to $4.6 \%$ lower second law efficiency than R134a did at all compressor speeds. 
In contrast, others (Zilio et al. [6]; Navarro-Esbrí et al. [10]; Pottker and Hrnjak [11]) have reported the reductions in COP and cooling capacity when using R1234yf as a drop-in replacement for R134a. In this context, various manners of increasing the COP in a vapour compression refrigeration system can be highlighted, such as the increase of the refrigerating effect in the evaporator by means of an IHX. Domanski et al. [12] made a theoretical evaluation for different refrigerants including R134a to obtain the IHX effects on the performance parameters. They implied that the IHX in the case of R134a has positive effect for COP and cooling capacity.

Furthermore, they found that the IHX caused an increase in the compression work due to a rise in the superheat degree of the system. Aprea et al. [13] claimed that IHX has an advantage in the system performance where the system requires low suction temperature and uses R134a as a working fluid. Accordingly, they presented an inequality between the COP and suction temperature. Then, they implied that the COP of the system tends to increase with increasing suction temperature with respect to the discharge temperature limits. In addition, they assumed that the specific heat at constant pressure was temperature independent and the pressure drops in the system was negligible. As a result, they found that inaccuracies were below $5 \%$ for different refrigerants.

Klein et al. [14] made detailed analysis with different refrigerants including R134a. They concluded that the reduction possibility of liquid containing vapour that could harm the compressor is the major benefit of the IHX. Additionally, it prevents the possibility of vapour containing liquid entering the expansion device. As a result, they showed that the relative capacity index for R134a was changed by $5 \%$, while the IHX effectiveness is $13 \%$.

Mastrullo et al. [15] experimentally investigated the performance of 19 ozone-friendly refrigerants. They claimed that the pressure drop of the liquid side in IHX is negligible, but the vapour side pressure drop has a significant influence on the system performance. They concluded that the rise in the pressure drop of the system causes the reduction in COP.

Hermes [16] claimed that the fair comparison for the system with and without IHX could be made in the case of supplying the same cooling capacity. In addition, he found that when the evaporation temperature of the refrigerant increases at a fixed condensation temperature, the COP of the system is decreased for R134a. Furthermore, he showed that the compressor discharge temperature of the refrigerant with IHX is higher than the basic cycle and this increment not only depends on the suction temperature of the compressor, but also depends on the changing evaporator pressure ratio.

Navarro-Esbrí et al. [17] found that the IHX is more effective for the system with R1234yf than R134a. They also showed that the cooling capacity and COP values improved by $2 \%$ and $6 \%$ when the IHX with $25 \%$ effectiveness is added to the system. Additionally, they pointed out that there were no significant changes with pressure drops when the IHX adapted to the system. Thus, they found unity with their theoretical calculations.

Cho and Park [9] determined that the COP of the system with R1234yf is improved by up to $4.6 \%$ when IHX was employed in the system.

Direk et al. [18] carried out an experimental analysis to compare the performance of R134a and R1234yf using a frigorific air conditioning system at different amount of charges. They claimed that the time dependent temperature gradient is compatible for both refrigerants.

Pottker and Hrnjak [11] demonstrated that the COP of the system with R1234yf is increased by increasing the sub-cooling degree of the condensed liquid refrigerant when IHX was used in the system. They used $1.5 \mathrm{~m}$ aluminium concentric double pipe IHX with $35 \%$ effectiveness in their system. They found that the presence of IHX increased the sub-cooling degree, thus the COP of their system is improved by $16 \%$.

This study extends the performance analysis of R1234yf as an alternative to R134a for an AAC system. For this purpose, an AAC experimental setup using R134a was developed to determine the drop-in performance of R1234yf. The drop-in performance analysis was performed under different compressor speeds and air stream temperatures. Then, the effect of IHX on the performance of the AAC system using R1234yf was investigated. The experimental performance of both refrigerants was discussed and compared in terms of the cooling capacity, COP and compressor discharge temperature.

\section{THERMODYNAMIC ANALYSIS}

When the system reaches the steady-state conditions, the first law of thermodynamics can be used to make energy analysis for each component of the system. During the analysis, kinetic energy and potential energy variance of the system were assumed to be negligible and the compression process was assumed to be adiabatic. Regarding the performance parameters of the system, cooling capacity $\left(\dot{Q}_{\text {evap }}\right)$ and $\left(\dot{W}_{\text {comp }}\right)$ 
values were calculated using Eq. 1 and Eq. 2. Fig. 1 symbolizes the paths of the system. Accordingly, the system without the IHX follows the cycle 1-2-3-4, and the one with IHX follows the cycle 1'-2'-3'-4'.

The cooling capacity $\left(\dot{Q}_{\text {evap }}\right)$ of the AAC system can be evaluated by:

$$
\dot{Q}_{\text {evap }}=\dot{m}_{r}\left(h_{1}-h_{4}\right),
$$

where $\dot{m}_{r}$ is the refrigerant mass flow rate and $h$ is the enthalpy of the refrigerant.

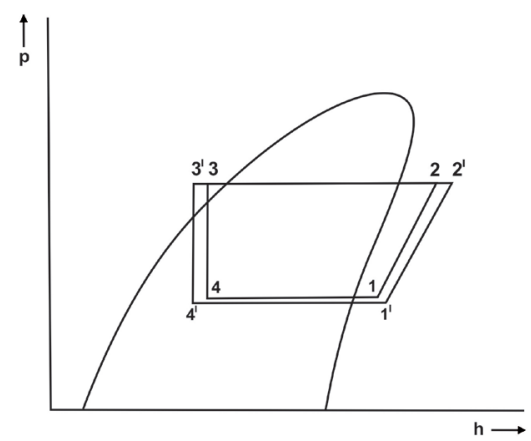

Fig. 1. P-h diagram of the system with and without IHX

The power absorbed by the refrigerant during the compression process can be evaluated by:

$$
\dot{W}_{\text {comp }}=\dot{m}_{r}\left(h_{2}-h_{1}\right) \text {. }
$$

The COP which is defined as the cooling capacity can be expressed by Eq. (3):

$$
C O P=\frac{\dot{Q}_{\text {evap }}}{\dot{W}_{\text {comp }}} .
$$

\section{EXPERIMENTAL SETUP}

The experimental system includes the conventional AAC system components as seen in Fig. 2. The system was composed of a belt-driven swash-plate compressor, a laminar micro-channel evaporator, a parallel-flow condenser and a thermostatic expansion valve (TXV). The compressor was connected to an electric motor with an inverter. The evaporator and condenser were mounted close to the discharges of two different 1-m long air channels. The AAC components specifications for the system are reported in Table 1.

$2 \mathrm{~kW}$ and $5 \mathrm{~kW}$ electrical resistance heaters were located in the evaporator and condenser channels to supply homogeneously heated air. A 900-mm doublepipe heat exchanger with $15.875 \mathrm{~mm}$ outer and 9.525 $\mathrm{mm}$ inner diameter was adapted to the system. A turbine type volume flow meter, which was located in the liquid line, was used to measure the refrigerant volume flow rate. K-type thermocouples were used to measure the refrigerant and air temperatures. The refrigerant pressures at the inlet and outlet of the compressor were monitored with a digital manifold. The measured variables were acquired through a data acquisition system and recorded on a computer. Characteristics of the instrumentation can be seen in Table 2.

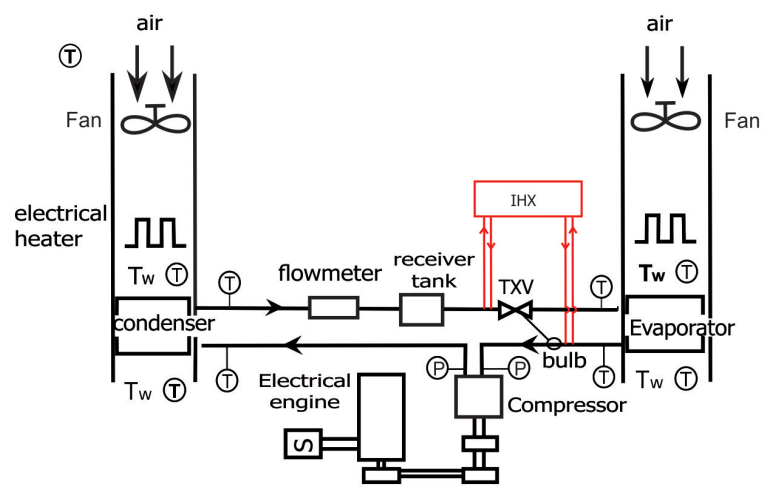

Fig. 2. Schematic diagram of the experimental setup

Table 1. Specifications of equipment of automotive air conditioning system

\begin{tabular}{ll}
\hline Component & Specification \\
\hline \multirow{2}{*}{ Compressor } & Stroke volume: $138 \mathrm{~cm}^{3}$ \\
\cline { 2 - 2 } & Cylinder numbers: 7 \\
\hline \multirow{3}{*}{ Condenser } & Max. speed: $5000 \mathrm{rpm}$ \\
\cline { 2 - 2 } & Capacity: $5.34 \mathrm{~kW}$ \\
\cline { 2 - 2 } Evaporator & Dimensions: $(635 \times 355 \times 20) \mathrm{mm}^{3}$ \\
\hline & Capacity: $5.23 \mathrm{~kW}$ \\
\cline { 2 - 2 } & Dimensions: $(210 \times 275 \times 70) \mathrm{mm}^{3}$ \\
\hline
\end{tabular}

Table 2. Specifications of the instrumentation

\begin{tabular}{llcc}
\hline $\begin{array}{l}\text { Measured } \\
\text { variable }\end{array}$ & Instrument & Range & $\begin{array}{c}\text { Uncertainty } \\
{[\%]}\end{array}$ \\
\hline Temperature [ ${ }^{\circ} \mathrm{C}$ ] & K-type thermocouple & -50 to 500 & \pm 0.5 \\
\hline Pressure [bar] & Digital manifold & 0 to 40 & \pm 0.75 \\
\hline $\begin{array}{l}\text { Humidity [\%] } \\
\text { Air velocity }\end{array}$ & Hygrometer & 10 to 100 & \pm 3 \\
\hline $\mathrm{ms}^{-1}$ ] & Anemometer & 0.1 to 20 & \pm 2 \\
\hline $\begin{array}{l}\text { Volume flow rate } \\
{\left[\mathrm{m}^{3} \mathrm{~s}^{-1}\right]}\end{array}$ & Turbine flow meter & 0.2 to 1.2 & \pm 1 \\
\hline
\end{tabular}

\subsection{Testing Procedure}

To compare the energy performance of the AAC system, experiments were conducted for R134a and 
R1234yf. Before the experiments, the air temperatures at the evaporator and condenser channels were set to $27^{\circ} \mathrm{C}$ or $35^{\circ} \mathrm{C}$ by the electrical resistance heaters. Additionally, the AAC system was charged with 960 $\mathrm{g}$ and $830 \mathrm{~g}$ in case of testing R134a and R1234yf, respectively. Furthermore, the fans were adjusted to supply appropriate air speed and the air flow rates with respect to the evaporator and condenser channels cross sections were evaluated $0.166 \mathrm{~m}^{3} \mathrm{~s}^{-1}$ and $0.501 \mathrm{~m}^{3} \mathrm{~s}^{-1}$, respectively. In addition, the relative humidity of the air streams measured between $50 \%$ to $70 \%$. The sub-cooling and superheat degrees were maintained between $5{ }^{\circ} \mathrm{C}$ to $8{ }^{\circ} \mathrm{C}$.

The experiments were performed under five different compressor speeds $(1000,1250,1500,1750$, and 2000) rpm. The steady-state conditions were achieved when the air stream temperatures within a tolerance of $\pm 0.5{ }^{\circ} \mathrm{C}$ and the sub-cooling and superheat degrees between $5{ }^{\circ} \mathrm{C}$ to $8{ }^{\circ} \mathrm{C}$. To ensure that the system attained steady-state conditions, experiments were performed with an additional 5 minutes.

\section{RESULTS AND DISCUSSION}

The influence of the compressor speeds on some of the performance parameters of the AAC system was demonstrated in Figs. 3 to 6. Fig. 3 shows the variation of cooling capacity with compressor speed when the air stream temperature at the inlet of the evaporator $\left(T_{\text {evap,ain }}\right)$ and condenser $\left(T_{\text {cond,ain }}\right)$ maintained at $27^{\circ} \mathrm{C}$. As seen in Fig. 3 the difference between cooling capacities of the system with R1234yf and R134a were increased as the compressor speed increased. In addition, the cooling capacity of the system with $\mathrm{R} 134 \mathrm{a}$ is higher than that of R1234yf at the same compressor speeds. The main reason for this is R134a has higher enthalpy difference value at the same temperature difference. Regarding the increasing compressor speed, the slope of the cooling capacity for R1234yf tends to decrease after $1250 \mathrm{rpm}$ in comparison with R134a. However, with adequate subcooling degree provided from the IHX, the cooling capacity difference in comparison with R134a is virtually the same after $1250 \mathrm{rpm}$.

Fig. 4 shows that the increasing compressor speed causes a decrease in COP of the AAC system. It is understood that the COP decreases exponentially whereas the compressor power increases linearly. This is because the cooling capacity does not have the same increasing tendency with the increasing compressor speed. Furthermore, the mass flow rate of the system with R1234yf was higher than that of R134a because of the higher pressure ratios.

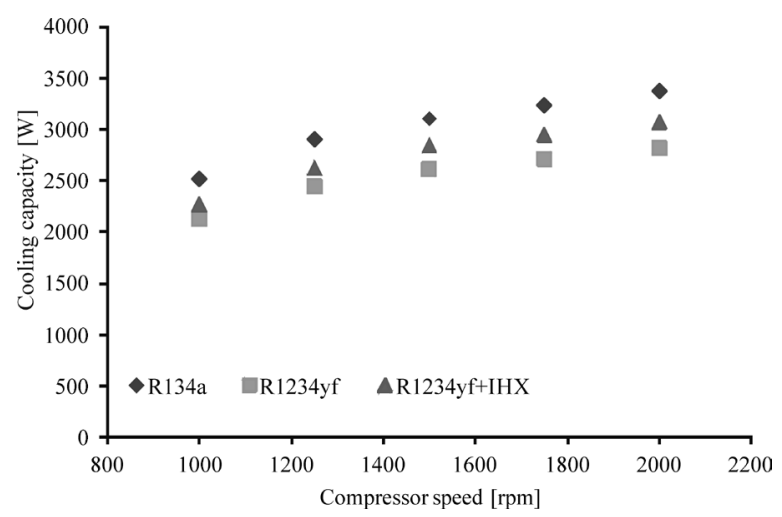

Fig. 3. Variation of $\dot{Q}_{\text {evap }}$ cooling capacity with compressor speed

$$
\left(T_{\text {evap, ain }}=T_{\text {cond, ain }}=27^{\circ} \mathrm{C}\right)
$$

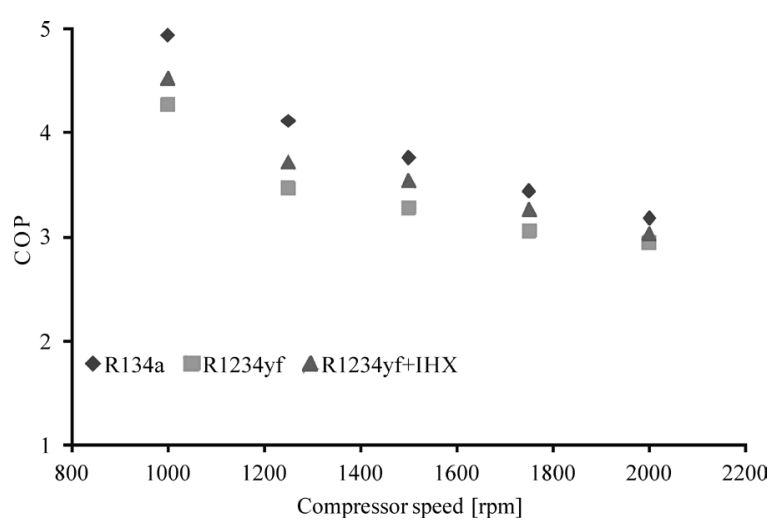

Fig. 4. Variation of COP with compressor speed

$$
\left(T_{\text {evap, ain }}=T_{\text {cond,ain }}=27^{\circ} \mathrm{C}\right)
$$

From Fig. 3 and 5, it can be understood that the cooling capacity difference increases when the air stream temperature is increased. For instance, at 1250 rpm, the cooling capacity of the system with R1234yf was $13.9 \%$ and $20.4 \%$ lower than that of R134a.

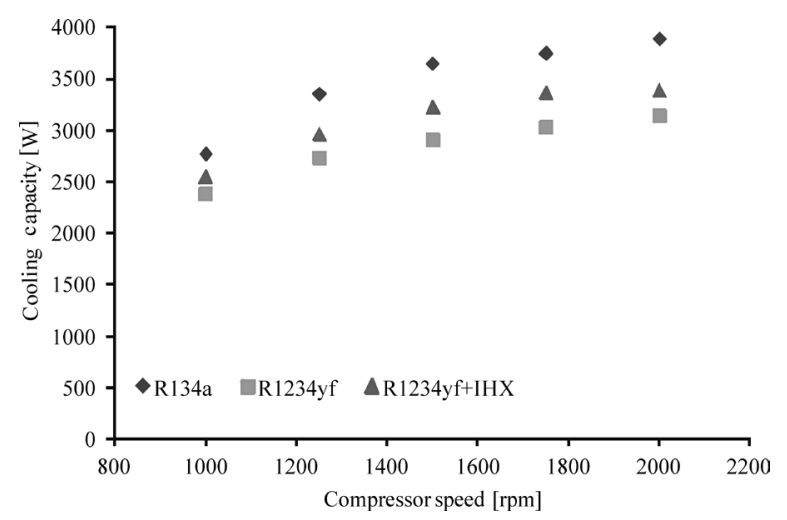

Fig. 5. Variation of cooling capacity with compressor speed

$$
\left(T_{\text {evap, ain }}=T_{\text {cond, ain }}=35^{\circ} \mathrm{C}\right)
$$




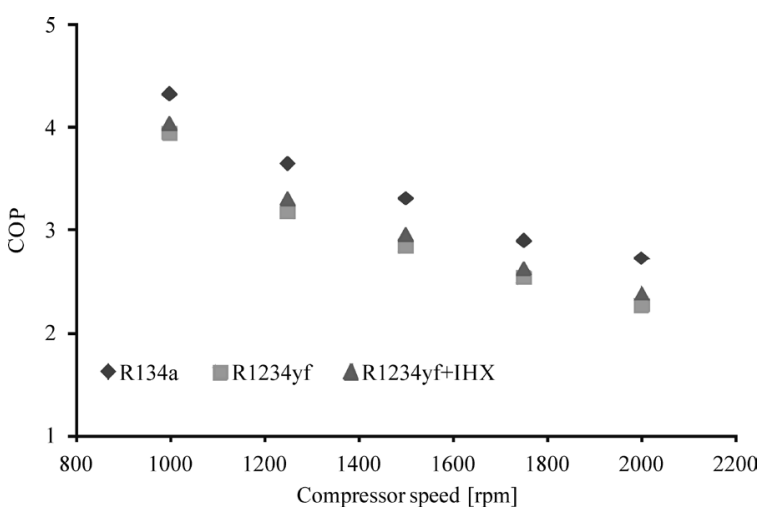

Fig. 6. Variation of COP with compressor speed

$$
\left(T_{\text {evap, ain }}=T_{\text {cond, ain }}=35^{\circ} \mathrm{C}\right)
$$

Figs. 3 to 6 demonstrated that the cooling capacity and COP are higher for the system with R1234yf when using IHX. The cooling capacity and COP for R1234yf were increased by $6.3 \%$ to $8.4 \%$ and $6.4 \%$ to $9.9 \%$, respectively when IHX used at the air stream temperatures of $27^{\circ} \mathrm{C}$ and $35^{\circ} \mathrm{C}$. It is noteworthy that the cooling capacity difference between R134a and R1234yf was decreased due to the achieved suitable sub-cooling degree when the IHX was used at high compressor speeds.

Fig. 7 indicates that the discharge temperature of the compressor increases with the higher level of superheating supplied. Additionally, when the IHX was adapted to the system, a $4.2{ }^{\circ} \mathrm{C}$ and $5.2{ }^{\circ} \mathrm{C}$ increment in the discharge temperature was observed for air stream temperatures of $27{ }^{\circ} \mathrm{C}$ and $35{ }^{\circ} \mathrm{C}$, respectively.

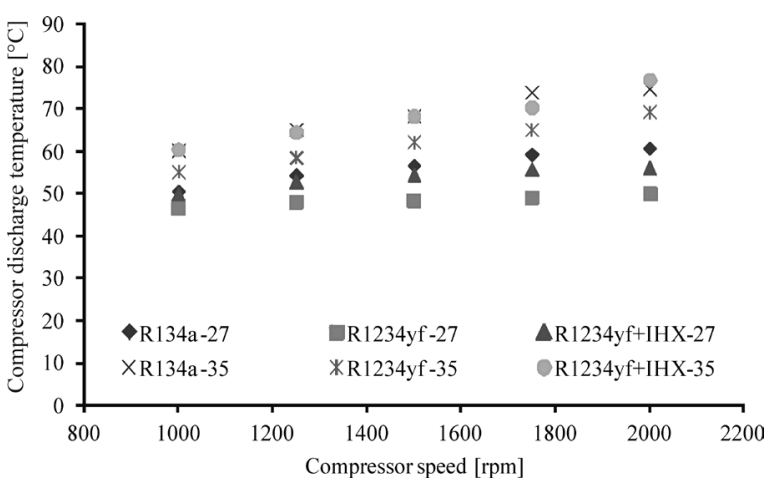

Fig. 7. Compressor discharge temperatures

However, R1234yf has lower discharge temperatures for all compressor speeds, with or without IHX in comparison to R134a. Thus, using R1234yf would not cause any detrimental issues in compressors with the same working conditions of R134a. That is why R1234yf will be a good alternative for the AAC system manufactured for R134a. In contrast, it was determined that the COP of the system for R1234yf was $7.5 \%$ to $15.7 \%$ and $8.85 \%$ to $16.8 \%$ lower in comparison to R134a for air stream temperatures of $27^{\circ} \mathrm{C}$ and $35^{\circ} \mathrm{C}$, respectively. Finally, it was observed that the rate of increase for both cooling capacity and COP was lower for air stream temperatures of $35^{\circ} \mathrm{C}$ in comparison to $27^{\circ} \mathrm{C}$.

\section{CONCLUSIONS}

The first aim of this study was to evaluate a drop in performance of R1234yf as a R134a replacement in the AAC system without any modification.

For this purpose, the cooling capacity and COP of the system were determined and presented as a function of compressor speeds and air stream temperatures. It was determined that the cooling capacity and COP of the system with R1234yf were $13.9 \%$ to $20.4 \%$ and $7.5 \%$ to $16.5 \%$ lower than that of R134a, respectively. Thus, it was proven that R1234yf can be a good drop in replacement of R134a not only because of the similar performance but also being a more environmentally friendly refrigerant considering the performance difference.

The second aim of the study was to determine the effect of IHX on the experimental system with R1234yf. For this reason, double pipe heat exchanger was selected and the experimental procedures were repeated. The results showed that the cooling capacity of R1234yf was improved by $6.3 \%$ to $8.6 \%$ and $6.4 \%$ to $9.9 \%$ for the air stream temperatures of $27^{\circ} \mathrm{C}$ and $35^{\circ} \mathrm{C}$, respectively. The compressor power was also increased due to the superheating effect of IHX and thus increasing the equivalent heat duty of the compressor. In addition, the COP of the system was increased by $2.8 \%$ to $7.4 \%$ and $2.4 \%$ to $4.8 \%$ for air stream temperatures of $27{ }^{\circ} \mathrm{C}$ and $35{ }^{\circ} \mathrm{C}$, respectively. After all the aforementioned analysis, it was determined that higher cooling capacity and COP can be achieved by using IHX for the system with R1234yf.

\section{ACKNOWLEDGEMENTS}

The authors would like to thank the University of Yalova for supporting this study through Research Project No: 2015/BAP/123.

\section{REFERENCES}

[1] Regulation (EU) No 517/2014 of the European Parliament and the Council of 16 April 2014 on Fluorinated Greenhouse 
Gases and Repealing Regulation (EC) No 842/2006 (2014). Official Journal of the European Union, Brussels.

[2] Directive 2006/40/EC of the European Parliament and of the Council of 17 May 2006 Relating to Emissions from Air Conditioning Systems in Motor Vehicles and Amending Council Directive 70/156/EC (2006). Official Journal of the European Union, Brussels.

[3] Regulation (EU) No 206/2012 of the European Parliament and the Council of 6 March 2012 Implementing Directive 2009/125/EC of the European Parliament and of the Council with Regard to Ecodesign Requirements for Air Conditioners and Comfort Fans (2012). Official Journal of the European Union, Brussels.

[4] Meyer, J. (2008). HFO-1234yf system enhancements and comparison to R134a. Proceedings of the SAE Alternative Refrigerant Systems Symposium, Phoenix.

[5] Daviran, S., Kasaeian, A., Golzari, S., Mahian, O., Nasirivatan, S., Wongwises, S. (2016). A comparative study on the performance of HFO-1234yf and HFC-134a as an alternative in automotive air conditioning systems. Applied Thermal Engineering, vol. 110, p. 1091-1100, D0I:10.1016/j. applthermaleng.2016.09.034.

[6] Zilio, C., Brown, J.S., Schiochet, G., Cavallini, A. (2011). The refrigerant R1234yf in air conditioning systems. Energy, vol. 36, no. 10, p. 6110-6120, D0I:10.1016/j.energy.2011.08.002.

[7] Qi, Z. (2013). Experimental study on evaporator performance in mobile air conditioning system using HFO-1234yf as working fluid. Applied Thermal Engineering, vol. 53, no. 1, p. 124-130, D0I:10.1016/j.applthermaleng.2013.01.019.

[8] Karber, K.M., Abdelaziz, O., Vineyard, E.A. (2012). Experimental performance of R-1234yf and R-1234ze as drop-in replacements for $\mathrm{R}-134 \mathrm{a}$ in domestic refrigerators. International Refrigeration and Air Conditioning Conference, Purdue, p. 2241-1-2241-10.

[9] Cho, H., Park, C. (2016). Experimental investigation of performance and exergy analysis of automotive air conditioning systems using refrigerant R1234yf at various compressor speeds. Applied Thermal Engineering, vol. 101, p. 30-37, D0I:10.1016/j.applthermaleng.2016.01.153.

[10] Navarro-Esbrí, J., Mendoza-Miranda, J.M., Mota-Babiloni, A., Barragán-Cervera, A., Belman-Flores, J.M. (2012). Experimental analysis of R1234yf as a drop-in replacement for
$\mathrm{R} 134 \mathrm{a}$ in a vapour compression system. International Journal of Refrigeration, vol. 36, no. 3, p. 870-880, D0l:10.1016/j. ijrefrig.2012.12.014.

[11] Pottker, G., Hrnjak, P. (2015). Experimental investigation of the effect of condenser subcooling in R134a and R1234yf air conditioning systems with and without internal heat exchanger. International Journal of Refrigeration, vol. 50, p. 104-113, D0I:10.1016/j.jijrefrig.2014.10.023.

[12] Domanski, P.A., Didion, D.A., (1994). Evaluation of suctionline/liquid-line heat exchanger in the refrigeration cycle. International Journal of Refrigeration, vol.17, no. 7, p. 487493, D0I:10.1016/0140-7007(94)90010-8.

[13] Aprea C., Ascani M., de Rossi, F. (1999). A criterion for predicting the possible advantage of adopting a suction/ liquid heat exchanger in refrigeration system. Applied Thermal Engineering, vol. 19, no. 4, p. 329-336, D0l:10.1016/S13594311(98)00070-2.

[14] Klein, S.A., Reindl, D.T., Brownell, K. (2000). Refrigeration system performance using liquid-suction heat exchangers. International Journal of Refrigeration, vol. 23, no. 8, p. 588596, D0I:10.1016/S0140-7007(00)00008-6.

[15] Mastrullo, R., Mauro, A.W., Tino, S., Vanoli, G.P. (2007). A chart for predicting the possible advantage of adopting a suction/ liquid heat exchanger in refrigerating system. Applied Thermal Engineering, vol. 27, no. 14-15, p. 2443-2448, D0l:10.1016/J. applthermaleng.2007.03.001.

[16] Hermes, C.J.L. (2013). Alternative evaluation of liquid-tosuction heat exchanger in the refrigeration cycle. International Journal of Refrigeration, vol. 36, no. 8, p. 2119-2127, D0I:10.1016/j.jijrefrig.2013.06.007.

[17] Navarro-Esbrí, J., Molés, F., Barragán-Cervera, Á. (2013). Experimental analysis of the internal heat exchanger influence on a vapour compression system performance working with R1234yf as a drop-in replacement for R134a. Applied Thermal Engineering, vol. 59, no. 1-2, p. 153-161, Dol:10.1016/j. applthermaleng.2013.05.028.

[18] Direk, M., Tunckal, C., Yuksel, F. (2016). Comparative performance analysis of experimental frigorific air conditioning system using R-134a and HF0-1234yf as a refrigerant. Thermal Science, vol. 20, no. 6, p. 2065-2072, D0l:10.2298/ TSCI140715130D. 